\title{
Characteristics of Saudi EFL Learners' Learning Styles
}

\author{
Khalid Al-Seghayer ${ }^{1}$ \\ ${ }^{1}$ College of Languages and Translation, Al Imam Mohammad Ibn Saud Islamic University, Riyadh, Saudi \\ Arabia \\ Correspondence: Khalid Al-Seghayer, College of Languages and Translation, Al Imam Mohammad Ibn Saud \\ Islamic University, Riyadh, Saudi Arabia.
}

Received: June 2, 2021

Accepted: June 16, 2021

Online Published: June 29, 2021

doi: $10.5539 /$ elt.v14n7p 82

URL: https://doi.org/10.5539/elt.v14n7p82

\begin{abstract}
One of the most important factors among those that play key roles in second language acquisition is language learning styles and strategies. This article identifies the unique and multifarious learning-style preferences that characterize Saudi English as a foreign language (EFL) learners' learning, and explores how multidimensional causal factors and experiences shape their preferred modes of learning. The analysis first tackles Saudi EFL learning-style preferences, followed by a discussion of Saudi EFL language learning strategies. The discussion addresses the learning-style approaches and learning behaviors of Saudi EFL leaners and the impact they have on them and highlights the factors and consequences of each. It concludes by pinpointing the importance of identifying language learning styles and strategies Saudi EFL students use and offering measures that will help Saudi EFL teachers facilitate their students' effective learning-style approaches.
\end{abstract}

Keywords: language learning styles and strategies, learning-style approaches, learning behaviors, English as a foreign language, Saudi English learners

\section{Introduction}

Learning-style preferences and language learning strategies are among the most crucial factors influencing successful language learning. According to Reid (1995), learning styles are individual, natural, habitual, and preferred ways of absorbing, processing, and retaining new information and skills. Language learning strategies, as defined by Oxford (1990), refer to "specific actions taken by the learner to make learning easier, faster, more enjoyable, more self-directed, more effective, and more transferable to new situations" (p. 8). Thus, language learning strategies refer primarily to the specific actions or behaviors that are consciously retained to achieve specific goals. Both concepts are influential variables because the attributes that individual learners bring to language learning affect English as a foreign language (EFL) learners' performance and success. As such, it is imperative to identify various language learning styles and strategies with reference to specific EFL contexts and EFL learners. Then, EFL language instructors in that particular context will be aware of their EFL learners' learning styles and strategies and able to develop EFL instruction tailored to their needs. Specifically, EFL instructors must be able to design effective and appropriate teaching methods, select suitable teaching materials, and develop activities and tasks that promote students' trajectory toward successful EFL acquisition. Moreover, EFL teachers will have a better understanding of effective language learning and learners.

When learning English, Saudi EFL learners use various unperceived or unconscious preferred learning styles. In particular, they use perceptual learning styles - visual, tactile, auditory, interactive, individual, and kinaesthetic - to perceive, organize, use, and retain language information via their senses. Saudi EFL learners then employ conscious language-learning strategies to expand their experience of learning English. However, in the Saudi context, rote learning and silent learning largely characterize Saudi EFL learning style approaches. These practices also guide students' learning behaviors in the classroom setting.

Accordingly, the goal of this paper is to provide a comprehensive profile of Saudi EFL learners' learning styles, with particular reference to their learning-style preferences and the learning processes through which they acquire English, such as commonly used language learning strategies, learning-style approaches, and learning behaviors. Each section is written as a more-or-less self-contained discussion. The paper concludes by highlighting the importance of identifying the learning-style preferences and learning strategies Saudi EFL learners employ most often, as well as the measures that Saudi EFL teachers might take to promote effective 
learning-style approaches, modify language-learning behaviors, and eliminate misbehavior among Saudi EFL learners.

The discussion's goals are outlined in the following two guiding questions:

1) What types of learning-style preferences and strategies do Saudi EFL learners employ most often?

2) What are the two learning style approaches that largely characterize Saudi EFL learners' learning?

\section{Saudi EFL Learning-Style Preferences}

Learning styles are concerned with how students prefer to learn, rather than what they learn. They are internally based characteristics of individuals for the intake or understanding of new information. Thus, a learning style refers to an individual's preferred methods of gathering, interpreting, organizing, and thinking about information as well as individual differences in his or her learning approaches based upon those preferences. English language learners shape their own learning process enormously. These learning styles can be distinguished into three main categories: cognitive style (field dependent versus field independent, analytic versus global, and reflective versus impulsive), sensory style (visual, auditory, tactile, or kinesthetic), and personality style (tolerance of ambiguity and right-brain versus left-brain dominance; Christison, 2003). A student's learning style is internalized and is often used unconsciously when acquiring EFL; it is a consistent way of functioning that reflects the underlying causes of learning behavior.

In the Saudi context, EFL learners largely prefer tactile and visual learning styles and show a strong preference for auditory, group, and kinesthetic learning styles. Thus, Saudi students tend to prefer visual and tactile activities, which suggests that they are more apt to use concrete sequential styles. At the same time, individual learning styles are least preferred among Saudi EFL students. In this case, cultural socialization factors and experiences shape their preferred modes of learning. For instance, Saudi culture places less emphasis or even a de-emphasis on individual work. Accordingly, Saudi EFL learners are uncomfortable with the ad hoc nature of individual or small group work in English classrooms. Because of the influence of their collectivist culture, these students demonstrate a strong preference for learning with others by asking questions and cooperating with peers.

Several empirical studies have supported this characterization of Saudi EFL learning-style preferences, and reported that Saudi EFL learners favor tactile, kinesthetic, auditory, and group styles and do not prefer individual styles of learning (see Figure 1). In Alkhatnai's (2011) study, 100 Saudi EFL students' perceptual learning styles were ordered from most to least preferred as follows: tactile, auditory, visual, group, kinesthetic, and individual. Although the tactile modality was the most preferred learning style, the visual modality was also strongly preferred. Similarly, Al-Hebaishi (2012) found that the majority of 88 Saudi EFL learners who were surveyed preferred a visual learning style, followed by auditory and kinesthetic styles. Along the same lines, Alkubaidi (2014) investigated Saudi EFL learners' learning style preferences, as one of the aims of the study, and found that the students could be ordered in terms of their language learning style preferences as group learners, visual, individual learners, auditory, kinesthetic, and tactile learning styles. The author proposed that such results can be ascribed to the fact that Saudi students prefer to be actively involved in the learning process and activities involving group or pair work, as opposed to working individually. Saudi students have a relatively high regard for active learning activities that give them a high level of control and autonomy over what they are doing. This speculation was confirmed by the results of Al-Dhafiri's study (2015), which examined the relationships between students' perceptions of their teachers' interpersonal behavior and their learning outcomes in EFL. Of the 200 Saudi EFL learners who participated in the study, 83.9\% (151) indicated that they like to work cooperatively with classmates during English lessons. These findings accentuate the role of ecological context as a mediating force influencing Saudi EFL learning-style preferences. Similarly, Al-Tale"s (2016) study, which examined the learning style preferences of 108 Saudi EFL learners' who were entering King Khalid University in Saudi Arabia, revealed that they used mixtures of the three primary learning styles (visual, auditory, and kinesthetic). Similarly, Khalil (2019) investigated the preferred learning styles of 120 Saudi EFL learners and found that they preferred the kinesthetic and tactile learning styles most often. 


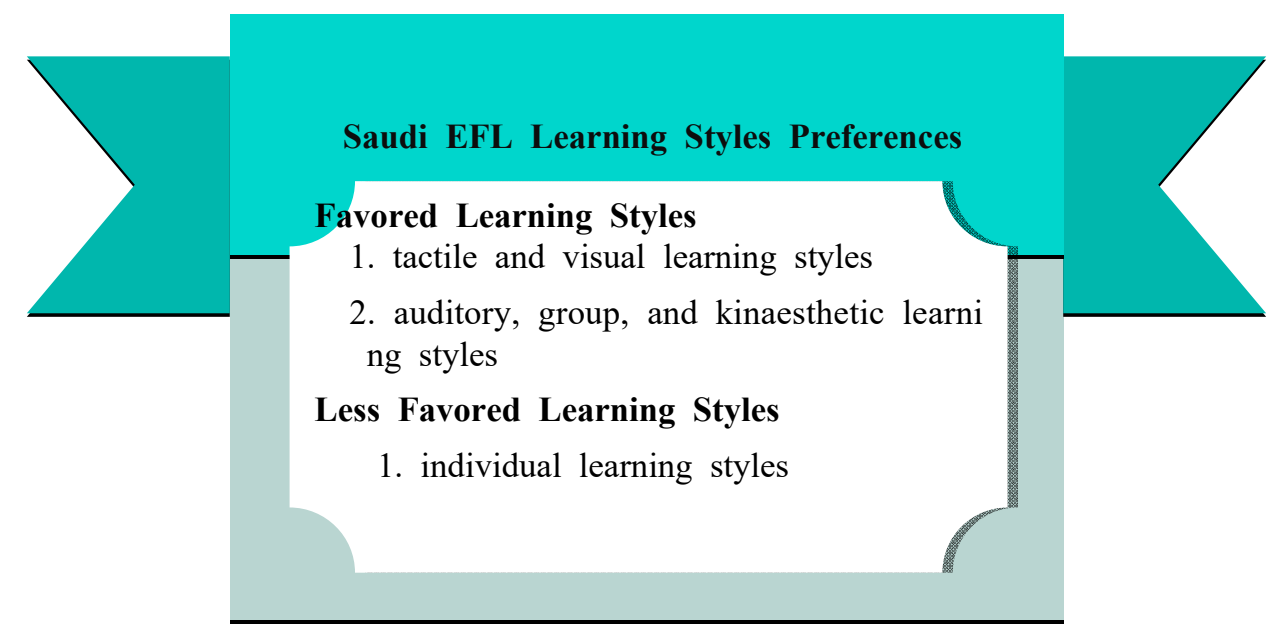

Figure 1. Saudi EFL learners learning styles preferences

\section{Saudi EFL Language Learning Strategies}

Saudi EFL learners also tend to employ similar language-learning strategies. Learning strategies are actions or techniques students use to enhance their language-learning experience. These strategies fall into six groups: cognitive, metacognitive, memory-related, compensatory, affective, and social.

Saudi EFL learners use language-learning strategies with low to medium frequency, which indicates that they are aware of the strategies at their disposal, but do not apply the full range of appropriate language-learning strategies (Al-Seghayer 2019). They prefer to use cognitive strategies (which involve deep processing of, forming, and revising internal mental models, and receiving and producing, messages in the target language) and metacognitive strategies (which involve exercising control over one's language learning by planning, organizing, monitoring, and evaluating to help learners gain control over their emotions and motivations related to language learning through self-monitoring). They use affective strategies (to manage feelings, attitudes, and motivations) and memory strategies (to store new information in memory and retrieve it when needed for communication) the least. In other words, overall, Saudi EFL learners prefer two out of the six strategy groups - cognitive and metacognitive strategies - the most and the other four strategy groups the least, particularly the affective and memory strategies.

This situation can be explained in several ways. It is generally assumed that in the Saudi context, students mainly learn English to advance their academic and overall progress in learning EFL, making the threat of failure a strong motivation. Thus, Saudi learners favor cognitive and metacognitive strategies because they allow the students to coordinate and maximize their language-learning process and help them gain control over their emotions and motivations related to learning English. These same students may avoid using affective strategies because they fear making linguistic mistakes and do not enjoy discussing their feelings with others.

With respect to Saudi learners' aversion to memory strategies, the Saudi education system emphasizes rote memorization in its instructional delivery system; however, students prefer to work and cooperate with their classmates rather than memorize information alone. This can be attributed to the fact that Saudi EFL learners may be searching for learning approaches that differ from the conventional didactic method. Alternatively, Alhaisoni (2012) suggested that the memorization strategy that characterizes Saudi EFL education differs from the specific memory techniques reported in language-learning strategies (e.g., using rhymes and flash cards to memorize new vocabulary, making a mental picture of a situation in which the word might be used, using rhymes to remember new words, and connecting the sound of a new English word with an image of the word to help remember the word). Unlike strict rote memorization, these memory techniques can improve students' cognitive processes in learning English and enhance their memory.

Several studies have closely explored the language-learning strategies Saudi EFL learners use (see Figure 2). For example, Al-Otaibi (2004) examined the language-learning strategies of Saudi EFL learners and found that Saudi learners of English used memory and cognitive strategies most frequently. This author also noted that social, affective, and compensation strategies were the least favored among EFL learners. Al-Refay and Koura (2010) attempted to identify the language learning strategies Saudi EFL learners use and ranked them from most preferred to least preferred, as follows: cognitive, metacognitive, memory, social, and affective. Alhaisoni (2012) reported similar results in his study, which investigated the type and frequency of language-learning strategies 
701 Saudi EFL learners used. He noted that Saudi learners use language-learning strategies at a low to medium frequency. The most frequent strategies they used included cognitive strategies (e.g., practicing, receiving, and sending messages, analyzing and reasoning, and creating structure for input and output) and metacognitive strategies (e.g., organizing, setting goals, planning language tasks, looking for practice opportunities, self-monitoring and self-evaluating). The least frequently used strategies were affective strategies (e.g., controlling anxiety, encouraging oneself, and taking one's emotional temperature) and memory strategies (e.g., asking questions, cooperating, and empathizing with others).

Similarly, Aljuaid (2015) identified the language-learning strategies Saudi EFL learners used. Her findings suggested that they share some common features, in that they used the memory strategy least, while the metacognitive strategy was the one used most commonly. Social, cognitive, and compensation strategies were used to an intermediate extent. Previously, Aljuaid (2010) examined the patterns of language-learning strategies used by 111 Saudi EFL learners. Her results revealed that students use learning strategies with medium frequency, although they used metacognitive strategies the most frequently and memory strategies the least. Consistent with these studies, Alkahtani (2016) investigated the type and frequency of language learning strategies 667 Saudi EFL learners used. The findings revealed that the participants used language strategies to a moderate extent, and metacognitive strategies were the most dominant strategy. The strategy categories were used in the following order: metacognitive, social, compensation, cognitive, memory and affective strategies.

Alhaysony (2017) also reached the same conclusion, as the 134 Saudi EFL learners in his study used cognitive, metacognitive, and compensation strategies the most frequently, while memory and affective strategies were used least often. Furthermore, the results showed that the strategies the participants used most often were used in the low to medium range, and that cognitive and metacognitive strategies were preferred highly and used to help them plan and organise their language learning.

To address Saudi EFL students' infrequent use of learning strategies and their failure to use the full range of strategies, teachers need to provide additional and more frequent opportunities for students to use appropriate language-learning strategies in different instructional tasks and activities. Moreover, the language strategies students were found to use least frequently, including affective, memory, and compensation strategies, should constitute the core of classroom strategy instruction. Teachers can help students use such strategies effectively by matching their teaching styles to each student's learning style and selecting appropriate instructional methods, tools, and materials to maximise students' use of learning styles and strategies. Ultimately, these measures will enhance the development of Saudi EFL learners' linguistic abilities.

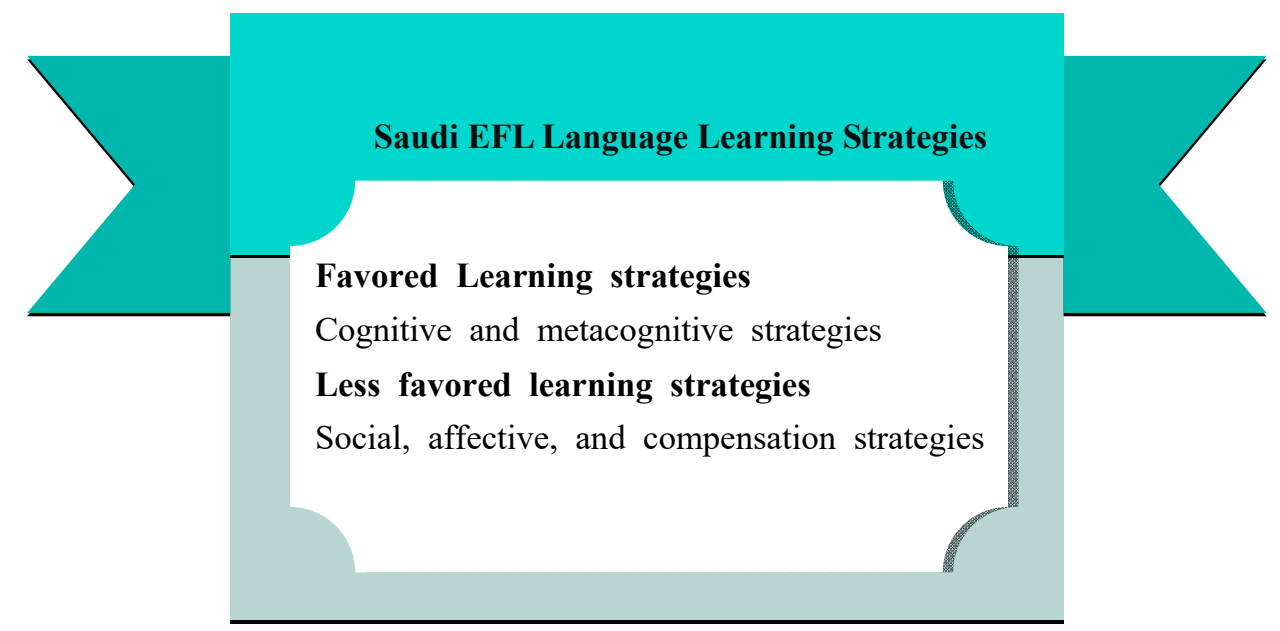

Figure 2. Saudi EFL Language Learning Strategies

\section{Saudi EFL Learning Style Approaches}

As previously noted, the two learning style approaches that primarily characterize Saudi EFL learners' learning are rote learning and silent learning (see Figure 3). The following describes each learning style that has a significant impact on Saudi EFL learners and highlights the factors that cause these learning style approaches and consequences of each on learning EFL. 


\subsection{Rote Learning}

Saudi EFL learners, from primary school to university, use rote learning strategies more frequently than other categories of memory or cognitive learning strategies to enhance permanency in their language learning. These rote or surface students prefer learning by rote over engaging in understanding, critical thinking, and practical skills. Thus, to gain linguistic knowledge and a thorough understanding of a text, Saudi students first employ repetition as a route to understanding - repetitive skill development comes first, followed by meaning and interpretation, with repetition being used to create meaning (Al-Seghayer 2017). This ubiquitous learning approach - which employs techniques such as mnemonics and silent reading, reading aloud, or written repetition of English language items in list form or on flashcards - involves repetitive content memorization and encourages excessive reliance on memorization to ensure accurate recall.

In general, effectively understanding and producing the spoken and written forms of a language depend on individuals' ability to recognize and retrieve information stored in their memory. Repetition (as a typical form of rote memorization) contributes to the storage and retrieval of language information. Thus, during the language-learning process, Saudi EFL learners tend to memorize grammatical rules, composition topics, new vocabulary, chunks of text, and textbook information and reproduce such information in their assignments or on exams. However, these students make prodigious efforts on English exams by memorizing answers without actually learning any English.

This pedagogical language approach does not involve any processes that enable students to understand or interpret the information they have learned. It is responsible for a minimum depth of learning during the activities that involve the processing of new information. Additionally, rote learning does not promote hypothetical reasoning, which is important for independent thinking, and it does not lead to permanent learning. It also does not stress hypothesis formation and learning through discovery in language learning. Students remain inactive learners and sometimes will not engage in class activities. Moreover, rote learning adversely affects students' creativity and critical thinking and leaves them unable them to cope with real-world challenges in this era of globalization. This is simply because mindless parroting of arbitrary and verbatim information does not lead to real understanding. Al-Rashidi and Phan (2015) contended that the main causes for low English language competence among Saudi EFL learners are their heavy reliance on rote learning and use of memorization as a primary learning strategy.

Several underlying factors enforce this type of learning and make it the sole learning instrument among Saudi EFL learners. For instance, Saudi EFL classrooms are typically teacher-centered and employ authoritarian teaching methods that maintain a passive role for students. The exam-driven Saudi educational system also places a heavy emphasis on accuracy. Accordingly, rote learning remains the predominant method for education in general and EFL in particular. Saudi EFL learners rely on memorization as part of the language-learning process and regard it as an important tool for learning. Teaching English in Saudi Arabia mainly adopts an audio-lingual approach, which projects that language learning is a matter of habit formation achieved through pattern practice and drilling activities. The approach ignores the development of thinking skills and so the absence of such focus contributes to the development of an English language education system based on rote learning.

Rote learning is also deeply rooted in Saudi tradition and culture and is a lamented aspect of pedagogical practice that is present at all educational levels. For example, Arabic children are rewarded for exhibiting memorization skills, and memorizing large parts of the Holy Quran is at the core of Saudi curricula (Abukhattala, 2013). Even the Arab saying "instruction during childhood is like carving on a rock" promotes rote learning. Overall, Saudi families are often prouder when their child possesses a stronger aptitude for memory (malakatu AlhifZ) than for understanding (malakatu Alfahm). Simultaneously, Saudi students' heavy dependence on their family prevents them from voicing differing opinions. Alqaedi (2013) further added that depending on oral communication make Arabs in general and Saudis in particular express themselves narratively using memorization.

The ideological underpinnings of Islamic education in early Saudi Arabia also inform the current emphasis on drills and repetition in the Saudi educational system. Kuttabs, a method of teaching in which memorization is the central method of learning, defined the first stage of Islamic education and has been carried into modern Saudi education (Elyas \& Al-Sadi, 2013). As Allamnakhrah (2013) explained, didactic rote learning and memorization, rather than understanding, remains the prevalent teaching method and learning process in Saudi Arabia. In reference to the realm of learning EFL, Al-Rabai (2014) noted that Saudi EFL teachers' dominance of English classes has caused students to be receptors, memorizers, and reproducers. Saudi EFL learners use memorization 
as their sole strategy for learning EFL; students memorize paragraphs, grammar rules, and vocabulary without understanding their meanings. In some cases, they are forced to memorize things they either do not comprehend or have no desire to learn, which ultimately leads them to participate ineffectively in the process of EFL learning or renders learning of English ineffective.

Thus, as Al-Harbi (2015) showed, the Saudi educational system regards English as a subject that can be broken into components to be memorized and regurgitated for exams, rather than a language to be learned. Teachers believe rote learning is the best way to teach students and emphasize memorization as a very important tool for successful language learning. Achievement is measured by students' ability to memorize the assigned language information. Thus, students are trained to regurgitate facts and often lack the thinking patterns or critical thinking skills necessary to apply their acquired knowledge to real-world problems.

As $50 \%$ of the participants surveyed in Hershberger and Farber's (2008) exploratory study emphasized, rote memorization produces little to no critical thinking skills. Accordingly, Hershberger and Farber argued that the most noticeable factor affecting Saudi EFL students' progress is rote learning and memorization, which involves Saudi EFL teachers transmitting uncontested language-related knowledge to their students. In the same vein, Mohammad and Hazarika (2016) noticed that memorization adversely affects Saudi EFL students' writing practices and leads to huge impediments in enhancing their writing skills. The results of their study, which investigates the difficulties that Saudi EFL students encounter when learning writing, showed that the 50 participants tended to memorize answers and paragraphs and then reproduce them verbatim in exams. The authors emphasized that memorization of factual knowledge is commonly practiced among Saudi EFL students and that deeper approaches to learning requiring higher levels of skills, such as analysis, synthesis, and evaluation of the instructional materials, are lacking in Saudi English education.

\subsection{Silent Learning}

Another unique characteristic of Saudi EFL students is their silence and reticence in English classrooms. Saudi students are passive knowledge absorbers and rarely question or challenge knowledge that is transmitted during English classes. They refuse or are unable to respond to direct questions and do not volunteer to answer teachers' questions or share opinions. They do not seek clarification or initiate interactions with their teachers in English. Overall, they do not appreciate or believe in the value of engagement and are usually unwilling to argue or to voice their opinions in class. Consequently, they choose to be silent to generate thoughts over the lesson's contents and turn to silence to disengage themselves from the classroom's happenings.

Accordingly, Saudi EFL students spend their class time listening to lectures or teachers, taking notes, and reproducing memorized information. They typically refrain from discussing the topic or commenting on other students' ideas and say no more than two or three words in class, even when teachers ask them to speak. For example, Al-Dhafiri (2015) found that only $10.7 \%$ of 200 Saudi learners surveyed voluntarily spoke during English classes. This preference for silent learning can be observed in all types of language-learning lessons - whether to learn the productive skills of speaking and writing or the receptive skills of reading and listening — at different educational levels and has a detrimental effect on students' participation levels.

Several interrelated sociocultural, psychological, and pedagogical factors as well as linguistic competence inform Saudi students' silence and passivity in classroom activities. Although each factor can independently account for classroom silence, they appear to be linked together and are accordingly well supported both educationally and culturally. Additionally, these factors shape Saudi learners' silent behavior in the Saudi EFL context and inhibit their participation in classroom discourses.

With respect to sociocultural factors, Saudi culture and tradition encourage individuals to respect hierarchical relationships and membership in social in-groups. In the Saudi social hierarchy, knowledgeable people such as scholars and teachers are respected as good role models. Thus, students regard teachers as all-knowing "founts" of knowledge and value that knowledge over anything they learn from partners or in working in small groups. Accordingly, deference to their teacher deeply shapes Saudi students' learning and engagement in EFL classrooms. Saudi EFL teachers are seen as the source of all knowledge and input; as a result, Saudi students do not value partners or small-group work, and they may be reluctant to work in pairs or groups. In fact, they have been culturally trained to comply with their teacher's demands.

Furthermore, cultural factors also inform Saudi learners' reticent behavior. Saudi culture emphasizes order and respect for authorities. As a result, English teachers are authoritarian, and students are quiet and obedient, which maintains silent learning. Listening attentively during class is seen as a sign of respect and as creating a productive learning environment; therefore, students prefer to listen and observe rather than engage in class discussion. During class, students are not allowed to interrupt their teacher for any reason. If they have questions, 
they are told to put up their hands and ask the question only with the teacher's permission. The opinion of the group is also valued more highly than that of the individual in Saudi culture; accordingly, to maintain group harmony, Saudi students only provide answers that match those of their peers. Moreover, they are reluctant to give negative responses out of fear of making their peers angry or being critical of each other. This is all due to the influence of the collective Saudi culture, in which individuals are expected to look after the well-being of the whole group as opposed to their individual well-being. As a result, their silence in this situation should be viewed as a sign of respect for their cultural values.

Deficiencies in linguistic competence further promote the prevalence of silent learning and Saudi students being unresponsive in English classrooms. Saudi students demonstrate low English-language proficiency, inaccurate pronunciation, poor grammatical accuracy, and limited lexical knowledge. These deficiencies make it difficult for students to express their ideas in English and therefore diminish their self-confidence and willingness to communicate in class. Thus, being less competent communicators in English causes students to feel insecure and rely upon silence to avoid verbal engagement in EFL classrooms. They may also find discovery-type activities frustrating.

Psychologically, one can attribute Saudi EFL learners' silence to disinterest, boredom, and frustration, as well as feeling overwhelmed and under pressure. However, these students also lack motivation and have a culturally ingrained fear of shame and embarrassment should they make a mistake in front of their peers. Thus, Saudi students prefer to remain silent because other classmates might detect their mistakes, view their language ability or pronunciation negatively, or think that their ideas are insignificant and criticize them. Believing that their ideal self-image is at risk if they speak, students withdraw into silence. They believe they are better off remaining silent than risking appearing foolish or being ridiculed when they respond inappropriately or inaccurately. As a result, a lack of confidence in English causes them to keep quiet in class or wait and see if somebody else has a better answer or comment.

Regarding the pedagogical factors behind students' silence, Saudi students are not guided or encouraged to develop skills in verbal analysis, argumentation, self-disclosure, and self-expression, even in their mother tongue. They are not taught the value or strategies of engagement. Furthermore, Saudi EFL lessons rarely incorporate discussion, debate, or argument because Saudi EFL teachers do not use student-centered participatory approaches, which promote active learning by giving all students the opportunity to take an active role in the language-learning process. In particular, teachers do not provide functional communication activities (such as comparing sets of pictures and noting similarities and differences, working out a likely sequence of events in a set of pictures, and discovering missing features in maps) or social interaction activities (such as conversation and discussion sessions, dialogues and role-play, simulations, skits, improvisation, and debates). Saudi teachers also fail to deliver lessons in more interactive ways that would encourage students to provide comments and become more open and actively engaged in activities. Additional factors such as Saudi EFL teachers' topic selection, ways of presenting the topic, ineffective questioning techniques and types of questions asked (i.e., with display and yes/no questions exceeding open/referential questions), and students' assigned roles only compound this issue of silence and reticence.

According to Alkubaidi (2014), this is due to Saudi academic culture, wherein teachers dominate the learning process, which is derived from the pedagogical faux pas of having a teacher-centered approach. English teachers spend the majority of the lesson talking, rarely allow students a chance to speak or ask questions, and give them few opportunities to practice language-skills activities. Thus, classes are usually quiet, as students take a passive role in the learning process and instead act as empty vessels or passive receptors blindly relying on teachers as full authority. Similarly, Al-Johani (2009) maintained that Saudi EFL teachers often engage themselves by illustrating and explaining the new language items under study during English class time, both verbally and by writing on the board, while Saudi EFL learners are passive listeners whose responsibility is to record what has been taught and copy from the board, thereby making them passive recipients in the classroom.

Overall, Hamouda's (2013) study confirmed this largely passive picture of Saudi EFL learners. In this case, low English proficiency, fear of public speaking, negative evaluations, shyness, lack of confidence and preparation, and fear of making mistakes promote Saudi students' silence or reticence in EFL classrooms. These factors make it difficult for students to adapt to different norms of verbal participation in EFL classrooms. 


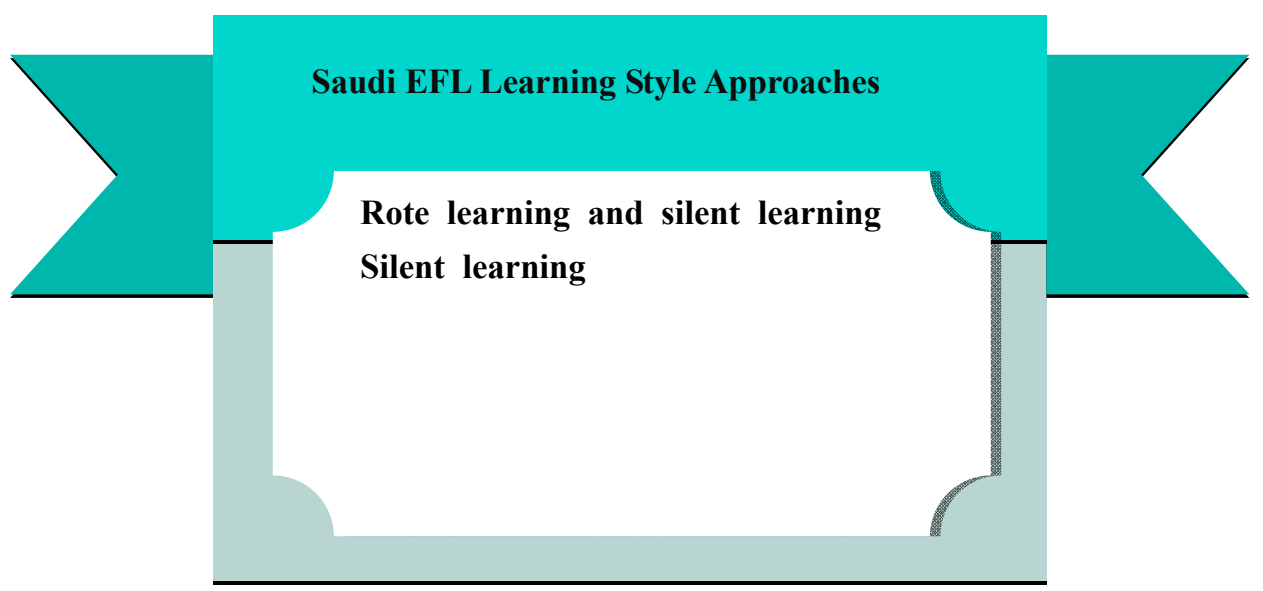

Figure 3. Saudi EFL Learning Style Approaches

\section{Saudi EFL Language-Learning Behaviors}

Finally, Saudi EFL learners exhibit various general and language-specific learning behaviors as they progress through the various stages of EFL acquisition. Both types of behaviors have been recognized as significant contributory factors in the process of language learning and in the ultimate success of EFL learners. This section will identify the two categories of learning behaviors among Saudi EFL learners in their English language learning along with the factors that contribute to each category and help the learners to acquire such learning aptitudes, attitudes, and learning values (see Figure 4).

\subsection{General Learning Behaviors}

Saudi EFL learners display a wide range of general learning behaviors, one of which is procrastination. Saudis often have relaxed attitudes toward time and, as such, do not regard deadlines as absolute. As a result, most Saudi students are very prone to putting off doing their homework and waiting until the last minute to complete assigned tasks. Delaying work that requires immediate attention can result in personal stress and inadequate or incomplete performance. In addition, many Saudi students do not take their studies seriously. When they are given assignments, they complete them simply to fulfill the course requirements, without showing any signs of taking them seriously. Furthermore, they often do not take responsibility for their own learning or tailor their learning conditions to create opportunities for practice outside their classrooms. They also have relaxed attitudes toward learning in general and are widely regarded as unmotivated in the classrooms.

Drawing on his 35 years of experience teaching Saudi learners, Hasan (2012) argued that Saudi EFL learners give up easily, do not work hard, and do not take extra steps to handle their learning tasks. They also fail to apply critical-thinking strategies to problem-solving tasks. Instead of seeking information themselves or participating in information retrieval, Saudi students rely on others for information, and their learning behaviors tend to be reactive instead of generative. Other behavioral features among Saudi students include regarding their teachers as the complete sources of knowledge, although they also rely on printed information and follow the behaviors of their particular groups. These students care more about test scores than about the learning process and just want to pass with minimal effort. They place the responsibility for their learning on the teachers or the circumstances. Thus, instead of admitting their wrongdoings or mistakes, Saudi students tend to place the blame on others and hold others responsible. In addition, the culture of pre-study and post-study is lacking among Saudi EFL learners, who often do not hold learning in particularly high esteem. Overall, Saudi students exhibit dependent tendencies and expect to be guided systematically through their learning. They do not approach academic achievement with intrinsic motivation and self-directed learning strategies.

\subsection{Language-Learning Behaviors}

With respect to language-learning behaviors, Saudi EFL learners at all levels exhibit learning behaviors that are generally restricted to the nonverbal or silent period of language acquisition. During this silent period, language students often choose not to speak, have trouble following directions, encounter difficulties in expressing their ideas and feelings, struggle with responding to questions consistently, and rely on simple yes/no responses and nonverbal communication. These students experience confusion regarding the locus of control, demonstrate poor attention, and show signs of shyness or withdrawal. Some of these behaviors are language-learning behaviors, while others are classroom behaviors. Furthermore, while some of the behaviors are directly observable, others are not. Additionally, some of these behaviors are associated with conscious learning, while others are related to 
the acquisition of and gains in general communicative competence. All of these behaviors influence the quality of the language-learning outcomes, and appropriate behaviors are crucial in achieving language growth as opposed to decay and restoration rather than destruction.

In the Saudi EFL classroom, students also continue to have difficulties in terms of expressing ideas and feelings and responding to questions that go well beyond the early stages of language acquisition. Some students pretend to understand English but shy away from exhibiting oral skills. Others may even ignore directions, exhibit defiance, and refuse to listen or participate. Thus, Saudi EFL learners often do not participate actively in class discussions or challenge the complexities of the English language. In addition, many do not try to associate new language items with learned ones and show little interest in analyzing, categorizing, and synthesizing the information they are given, to classify it and identify language patterns. Overall, many Saudi students demonstrate a lack of interest in English lessons and a lack of commitment to learning English. As a result, they rarely seek opportunities to practice speaking, which would enable them to use English in an authentic communicative context and observe how native speakers use it, and consequently to enrich their language and help them to make necessary changes in their approaches and study skills. In addition, students do not always cooperate with planned activities or come to classes properly prepared and often do not revise what is taught in the classes or study at home in an organized manner.

Some students also engage in activities and behaviors that not only contradict social customs and ethical beliefs but also jeopardize the productivity of the classroom environment. Hasan (2012) cites some common examples of these types of poor language-learning behaviors. They include excessive tardiness and absences, chatting, asking irrelevant questions, being overtly inattentive (such as sleeping, talking to classmates, and passing notes), exhibiting overtiredness, not completing homework assignments (often using excuses such as "I did not understand what to do"), doing only last-minute preparation, turning in incomplete work, and exerting the minimum effort necessary to achieve high grades or being satisfied with borderline scores. In a study by Hershberger and Farber (2008), Saudi EFL teachers indicated that their students were disorganized (59\%), procrastinated (54\%), accepted little responsibility for their learning $(84 \%)$, and did not connect English language abilities with academic success $(46 \%)$. According to these teachers, although their students were interested and engaged on an individual basis, their study skills were poorly developed, and they needed to take more responsibility for their own language learning. In a similar study, Makrami (2010) looked at the motivation, anxiety, and attitudes of 507 Saudi EFL learners toward learning English. The results of the study revealed that these learners were distracted from the learning process because they talked loudly, often came to class late, and did not concentrate on their learning or on maintaining discipline in the classroom. All of these behaviors resulted in the Saudi EFL learners lackadaisical towards English and not enjoying English language learning; additionally, their pace in learning English at appropriate levels was abysmally disappointing. Overall, to most Saudi students, obtaining good grades and degrees are more important than acquiring the knowledge and skills to match their respective degrees (Razek, 2014). Hence, teaching Saudi students is challenging and difficult, and they lack the knowledge of what it takes to succeed.

Springsteen (2014) also noted that Saudi learners do not handle conflict well when negotiating for higher grades or managing their attendance and project due dates. In other words, Saudi students avoid discussing course performance or problems with their teachers, choosing instead to try to negotiate favorable results concerning grades, assignments, or course requirements. In doing so, the students sometimes argue inappropriately with their teachers and challenge them in negative tones of voice, thereby demonstrating disrespect. This behavior may result from the pressure that is put on students to pass their exams. Also, because testing is primarily based on subjective instruments in the Saudi educational system, Saudi learners tend to be able to negotiate the grades that they receive. Indeed, the relative subjectivity of essay-based tests leaves ample room for learners to negotiate. Habbash and Idapalapati (2016) looked into the language behavior of Saudi EFL students from various perspectives including their classroom behavior, learning attitudes, and learning styles and found that, according to their instructors, they held unique and distinctly adverse aspects with regard to all three. For example, Saudi EFL learners tend to do homework not as a learning assignment but as a drudgery to be completed as quickly as possible, and some of them refuse to cooperate, misbehave, and keep disrupting the entire class.

Saudi EFL learners sometimes engage in academic dishonesty as well, through cheating, giving or receiving unauthorized help on assignments, and copying from other students' tests or homework. Such academic misconduct may result from the strong Saudi tradition of being loyal to those closest to you. Allegiances, in fact, may be powerful enough that a student could feel honor-bound to help a compatriot with homework, with a research paper, and in a testing environment (Matson, 2016). 
Various factors influence the pervasiveness of the general and language-related learning behaviors that are noted above. For instance, Saudi EFL teachers, especially novices, are not well prepared for managing English classes or enforcing discipline. They are incapable of managing classroom behavior and maintaining classroom environments that are conducive to effective language teaching and learning. The novice teachers lack information about disciplinary measures, methods of handling conflict, and the means to identify and manage certain negative language-learning behaviors. Although these teachers may possess expertise in English teaching, they are not experienced in forming alliances with their students, establishing conditions to promote students' engagement with the curriculum, providing intellectually challenging learning experiences, organizing and managing classes to facilitate English language learning, or making positive impacts on the teaching-learning process. Elsheikh, Babiker, and Abu Alhassan (2014) presented a similar argument that Saudi EFL education lacks an educational strategy to enable Saudi EFL teachers to improve their students' motivation to achieve more, since this type of incentive is an effective conative factor that determines the direction of an individual's behavior toward an end or goal; that is, to acquire EFL knowledge successfully.

Finally, opinions regarding the need to learn English as well as the factors that constitute acceptable behavior in the students' homes inform their behaviors in the EFL classroom. Many Saudi students have been indulged by their families throughout their lives, so that they see no need to study hard and are not interested in learning. Students who have been spoiled at home may also engage in behaviors that simply reflect desires for extra attention, to escape or avoid demanding situations, to exert control, and to demonstrate their dislike of English language courses. Indeed, the attitudes of a considerable number of Saudi parents aggravate such situations, because they are indifferent toward English. In addition, as Khan (2011) claims, in the eyes of Saudi parents it is the teachers who are supposed to act as guardians or parents in motivating and guiding their children in their English classes.

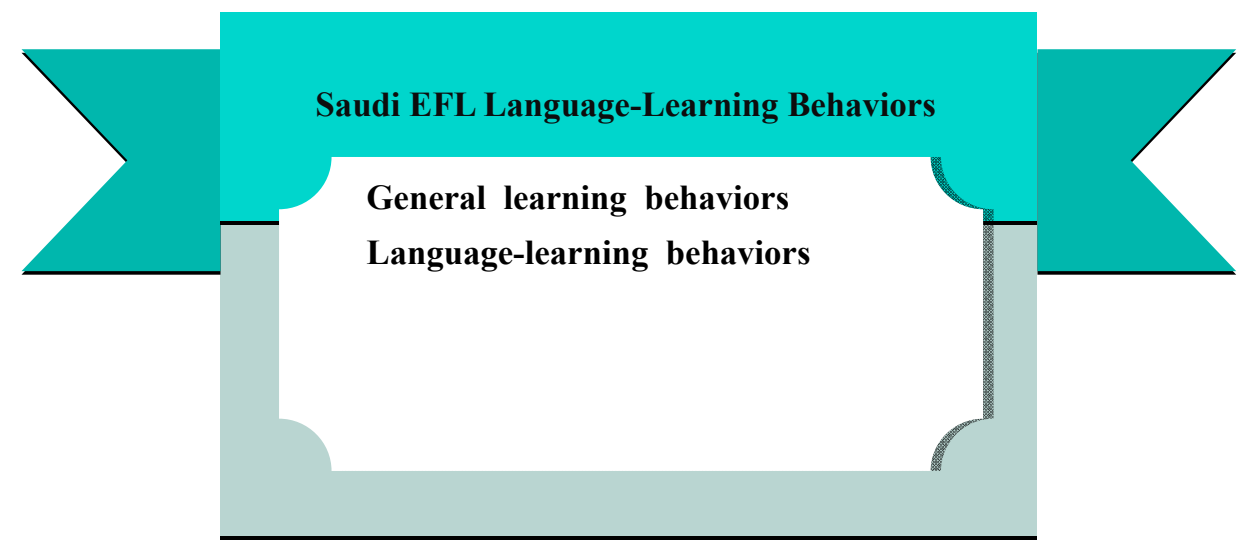

Figure 4. Saudi EFL language-learning behaviors

\section{Closing Remarks}

This paper identifies the types of preferences with regard to the learning styles and learning strategies that are most frequently used by Saudi EFL learners, as these are among the most crucial factors that influence the language-learning process and the success or failure of language learning. The discussion shows tactile and visual learning styles to be the top choices for Saudi EFL students, who also prefer auditory, group, and kinesthetic learning styles. In addition, Saudi EFL students prefer cognitive and metacognitive strategies, while their least favorites are social, affective, and compensation strategies. Rote learning and silent learning largely characterize Saudi EFL learning styles, and these practices also give direction to the learning behaviors of students in classroom settings. Saudi EFL learners display a wide range of challenging general language-learning behaviors as well as distinguishable patterns of language-learning behaviors.

Because Saudi EFL students use language strategies and build on their knowledge, recognizing and identifying their preferences with regard to learning styles and the types of language-learning strategies they use are essential steps in creating more efficient and successful environments for learning English. This information will also help to provide a deeper understanding of the relationship between language-learning strategies and language achievement within the Saudi EFL context. Armed with such knowledge, Saudi English-language teachers and other stakeholders involved in enhanced language training in Saudi Arabia will be able to improve the EFL learning process by addressing and enhancing the specific preferences of students with regard to learning styles and strategies in performing tasks and processing information. Saudi teachers can also help 
students to become more aware of their preferred learning strategies and about how to control the ways in which they approach the task of learning English, to become more efficient, motivated, and independent and consequently more responsible in terms of adopting their own preferences. It is equally important for teachers to be able to provide a wide range of learning strategies to meet the different needs and expectations of their students that are based on their preferred learning styles.

Identifying the learning styles and language-learning behaviors of Saudi EFL learners is also a necessary step toward understanding the following: (a) the psychological mechanisms involved in creating, shaping, and guiding language learning styles and behaviors, (b) the learning factors related to both areas that affect language learning, (c) how to manage a suitable classroom environment for learning EFL, by supporting the development of Saudi students and helping them increase their efficiency in language learning, and (d) individual language-learning performance and outcomes. In addition, identifying these learning styles and language-learning behaviors and reflecting on their potential impacts on language learning and teaching can inform all Saudi stakeholders who are involved, including curriculum designers, policy makers, and teachers, with regard to what it takes to develop an effective EFL classroom environment.

Saudi EFL teachers could adopt a number of measures to promote effective learning styles, modify language-learning behaviors, and eliminate misbehavior among Saudi EFL learners. Some of these important measures and solutions to current problems include providing activities that allow students to examine these learning styles and language-learning behaviors as well as the possible impacts they have on the students' experiences in learning English. Teachers should also consider raising students' awareness of the wide range of options that are available to them with regard to strategies for learning. Exposing students to effective language-learning strategies on a regular basis may enable them to use the strategies more efficiently during the process of their EFL learning. Teachers should work with students to help them to discover for themselves the methods and techniques that help them to learn best, as well as to teach them how to take charge of their own learning at the beginning of the learning process. In this way, teachers can help students to identify the strategies that are most suitable to their learning styles, tasks, and goals, and assist them in developing organized strategies rather than taking scattered approaches. Students will then be aware of the most effective learning styles and strategies to adopt for themselves, and this could help them to improve their learning processes in other contexts as well. Teachers should also reward desirable language-learning behaviors and set standards for appropriate behaviors that create positive environments for learning English. Teachers can achieve this by seeking to engage students in understanding, critical thinking, and practical skills, rather than simply adding more language-related information to their lessons. In addition, Saudi EFL teachers should make use of all the oral tasks to provide learners with sufficient practice in active oral participation and help them through the different stages, so that they have opportunities to learn English and develop confidence in both their fluency and their accuracy. Another option is to combine multiple learning styles to make lessons more vivid and interesting. Overall, insightful knowledge of the characteristics of the learning styles of Saudi EFL learners will contribute to a more conducive learning environment and result in more effective EFL learning.

\section{References}

Abukhattala, I. (2013). What Arab students say about their linguistic and educational experiences in Canadian Universities. International Education Studies, 6(8), 31-37. https://doi.org/10.5539/ies.v6n8p31

Al-Dhafiri, N. (2015). The role of interpersonal EFL teacher behaviour in enhancing Saudi students' learning. International Journal of English Language Teaching, 2(1), 47-55. https://doi.org/10.5430/ijelt.v2n1p47

Alhaisoni, E. (2012). Language learning strategy use of Saudi EFL students in an intensive English learning context. Asian Social Science, 8(13), 115-127. https://doi.org/10.5539/ass.v8n13p115

Al-Harbi, A. (2015). A descriptive-evaluative study of a Saudi EFL textbook series. Cogent Education, 2(1), 2-26. https://doi.org/10.1080/2331186X.2015.1079946

Alhaysony, M. (2017). Language learning strategies use by Saudi EFL students: The effect of duration of English language study and gender. Theory and Practice in Language Studies, 7(1), 18-28. https://doi.org/10.17507/tpls.0701.03

Al-Hebaishi, S. (2012). Investigating the relationships between learning styles, strategies and the academic performance of Saudi English majors. International Interdisciplinary Journal of Education, 1(8), 510-520. https://doi.org/10.12816/0002890 
Al-Johani, H. M. (2009). Finding a way forward the impact of teachers' strategies, beliefs and knowledge on teaching English as a foreign language in Saudi Arabia (Unpublished doctoral dissertation). University of Strathclyde, Glasgow, Scotland.

Aljuaid, H. (2010). Language learning strategies: Perceptions of female Saudi EFL learners. In Kaufhold, K., McCulloch, S., \& Tominc, S. (Eds.), Papers from the Lancaster University Postgraduate Conference in Linguistics \& Language Teaching (pp. 2-24). Griffith University, Brisbane, Australia.

Aljuaid, H. (2015). Language learning strategies used by group of Saudi Arabian EFL learners (Unpublished doctoral dissertation). Griffith University, South East Queensland, Australia.

Alkahtani, S. (2016). Language learning strategies among Saudi EFL college students and their relationship to students' perceptual learning style, gender, academic major and proficiency level (Unpublished doctoral dissertation). University of Tennessee, Knoxville.

Alkhatnai, M. (2011). Learning styles of EFL Saudi college-level students in online and traditional educational environments (Unpublished doctoral dissertation). Indiana University of Pennsylvania, Indiana, PA.

Alkubaidi, M. (2014). The relationship between Saudi English major university students' writing performance and their learning style and strategy use. English Language Teaching, 7(4), 83-95. https://doi.org/10.5539/elt.v7n4p83

Allamnakhrah, A. (2013). Learning critical thinking in Saudi Arabia: Student perceptions of secondary pre-service teacher education programs. Journal of Education and Learning, 2(1), 197-210. https://doi.org/10.5539/jel.v2n1p197

Al-Otaibi, G. (2004). Language learning strategy use among Saudi EFL students and its relationship to language proficiency level, gender and motivation (Unpublished doctoral dissertation). Indiana University of Pennsylvania, Indiana, PA.

Alqaedi, N. (2013). Rhetorical transfer of L1 repetition and transition words into English texts: The case of Saudi students (Unpublished master's thesis). Gonzaga University, Spokane, WA.

Al-Rabai, F. (2014). Motivational practices in English as a foreign language classes in Saudi Arabia: Teachers' beliefs and learners' perceptions. Arab World English Journal, 5(1), 224-246.

Al-Rashidi, O., \& Phan, H. (2015). Education context and English teaching and learning in the Kingdom of Saudi Arabia: An overview. English Language Teaching, 8(5), 33-44. https://doi.org/10.5539/elt.v8n5p33

Al-Refay, N., \& Koura, A. (2010, 26-27 October). Language learning strategies used by Saudi secondary school students and their relationship to achievement in EFL. Paper presented at the 30th CDELT, National Symposium on English Language Teaching, Ain Shams University, Cairo, Egypt.

Al-Seghayer, Khalid. (2017). Reality and Challenges of TEFL in 21st-Century Saudi Araba. Saudi Arabia: Hala Printed Co.

Al-Seghayer, Khalid. (2019). Unique challenges Saudi EFL Learners Face. Studies in English Language Teaching, 7(4), 490-515. https://doi.org/10.22158/selt.v7n4p490

Al-Tale', M. (2016). Utilizing learning styles in EFL teaching. International Journal of Language and Linguistics, 3(6), 81-86.

Christison, M. A. (2003). Learning styles and strategies. In D. Nunan (Ed.), Practical English Language Teaching (pp. 267-288). New York, NY: McGraw-Hill.

Elsheikh, F., Babiker, A., \& Abu Alhassan, A. (2014). A proposed strategy to improve the Saudi university students' motivation towards learning English as a foreign language. American Journal of Research Communication, 2(4), 32-50.

Elyas, T., \& Al-Sadi, A. (2013). Critiquing of higher education policy in Saudi Arabia: A neoliberalism approach. Education, Business and Society: Contemporary Middle Eastern Issues, 6(1), 31-41. https://doi.org/10.1108/17537981311314709

Habbash, M., \& Idapalapati, S. (2016). Distinctiveness of Saudi Arabian EFL Learners. Advances in Language and Literary Studies, 7(2), 113-120. https://doi.org/10.7575/aiac.alls.v.7n.2p.113

Hamouda, A. (2013). An exploration of causes of Saudi students' reluctance to participate in the English language classroom. International Journal of English Language Education, 1(1), 17-34. https://doi.org/10.5296/ijele.v1i1.2652 
Hasan, A. (2012). Saudi learner issues. In W. Al-Amri, H. Noor \& I. McGee (Eds.), Saudi preparatory year English program: The future and beyond: student, teacher, pedagogy, and curricular issues (pp. 7-17). Al-Madinah Al-Mounwarh, Saudia Arabia: Taibah University.

Hershberger, J., \& Farber, G. (2008). How teachers, administrators, and classmates perceive Saudi Arabian students. Directions for Teaching and Learning, 77, 3-10.

Khalil, A. (2019). Saudi EFL learners' perceptual learning-style preferences. Education and Linguistics Research, 5(2), 117-133. https://doi.org/10.5296/elr.v5i2.15711

Makrami, B. (2010). Motivation and attitudes of Saudi university's learners of English for specific purposes (Unpublished doctoral dissertation). University of Kansas, Lawrence, KS.

Matson, S. (2016). Suggestions for helping Saudi Arabian students adjust to the Western educational setting. Retrieved from https://languagemagazine.com/?page_id=6364

Mohammad, T., \& Hazarika, Z. (2016). Difficulties of learning EFL in KSA: Writing skills in context. International Journal of English Linguistics, 6(3), 105-117. https://doi.org/10.5539/ijel.v6n3p105

Oxford, R. (1990). Language learning strategies: What Every Teacher Should Know. New York: Newbury House.

Razek, N. (2014). Academic integrity: A Saudi student perspective. Retrieved from https://www.academia.edu/17465413/Academic_Integrity_A_Saudi_Student_Perspective

Reid, J. M. (Ed.) (1995). Learning styles in the ESL/EFL classroom. Boston: Heinle and Heinle.

Springsteen, S. (2014). Examining student motivation in Saudi Arabia (Unpublished master's thesis). SIT Graduate Institute, Brattleboro, VT.

\section{Copyrights}

Copyright for this article is retained by the author(s), with first publication rights granted to the journal.

This is an open-access article distributed under the terms and conditions of the Creative Commons Attribution license (http://creativecommons.org/licenses/by/4.0/). 